\title{
Agronomic performance and interspecific hybrids selection of the genus Paspalum
}

\section{Desempenho agronômico e seleção de híbridos interespecíficos do gênero Paspalum}

\author{
Emerson André PEREIRA ${ }^{1}$; Miguel DALL'AGNOL ${ }^{1}$; Carine SIMIONII; Juliana Medianeira MACHADO ${ }^{1}$; \\ Mêmora Giovana Schmidt de BITENCOURT ${ }^{1}$; Divanilde GUERRA ${ }^{1}$; Emilio Ghisleni ARENHARDT ${ }^{2 *}$; \\ José Antonio Gonzalez da SILVA ${ }^{2}$ \\ 1 Universidade Federal do Rio Grande do Sul, Faculdade de Agronomia, Departamento de Plantas Forrageiras e \\ Agrometeorologia, Avenida Bento Gonçalves, n. 7.712, CEP 91501970 Porto Alegre, RS. E mail: \\ emersonpijui@gmail.com.br; migueld@ufrgs.br; carini.simioni@ufrgs.br; juliana.machado@yahoo.com.br; \\ meminha@gmail.com; divanilde.guerra@hotmail.com \\ ${ }^{2}$ Universidade Regional do Noroeste do Estado do Rio Grande do Sul, Departamento de Estudos Agrários, Rua do Comércio, \\ no 3.000, CEP 98700000, ljuí, RS. E mail: emilio.arenhardt@yahoo.com.br; jagsfaem@yahoo.com.br
}

Recebido em: 23-12-2014; Aceito em: 04-05-2015

\begin{abstract}
The objective of the study was to analyze the genetic variability at agronomic and molecular level of apomictic genotypes of the genus Paspalum obtained by interspecific crosses of Paspalum plicatulum (sexual famale genitor) and Paspalum guenoarum (apomictic male genitor) to predict promising combinations with the sexual genitor using characters related to forage production. The study was conducted in two environments in 2010 and 2011 in Eldorado do Sul and Augusto Pestana, State of Rio Grande do Sul, Brazil. The experiment followed a randomized block design with four replicates at both locations. Seven interspecific hybrids, the two genitors (sexual "4c-4x" P. plicatulum and apomictic cultivate "Rojas" $P$. guenoarum) and two native genotypes of Paspalum guenoarum and cultivate Pensacola of $P$. notatum were used. Analysis done inagronomic and molecular levels were able to detect genetic variability among interspecific hybrids of Paspalum. Moreover, the results suggested that the hybrids $\mathrm{H} 12, \mathrm{H} 13$ and $\mathrm{H} 20$ are recommended for further hybridizations with female sexual parent obtaining elite recombinant.
\end{abstract}

Additional keywords: apomixes; forage species; genetic variability; plant breeding.

\section{Resumo}

O objetivo do estudo foi analisar a variabilidade genética em nível agronômico e molecular de genótipos apomíticos do gênero Paspalum obtidos pelo cruzamento interespecífico de Paspalum plicatulum (genitor feminino sexual) e Paspalum guenoarum (genitor masculino apomítico), buscando prever combinações promissoras com o genitor sexual em caracteres ligados à produção de forragem. O estudo foi conduzido nos anos de 2010 e 2011, em Eldorado do Sul e em Augusto Pestana-RS, Brasil. O delineamento experimental foi o de blocos casualizados, com quatro repetições, em ambos os locais. Foram utilizados sete híbridos interespecíficos e genitores (sexual "4c-4x" de P. plicatulum x cultivar apomítica "Rojas" de P. guenoarum), incluindo dois genótipos nativos de Paspalum guenoarum e a cultivar Pensacola de Paspalum notatum. Foram realizadas análises agronômicas com os dados de campo, e na análise molecular foi usado o marcador do tipo SSR. A análise observada em nível agronômico e molecular foi capaz de detectar variabilidade genética entre os híbridos apomíticos interespecíficos de Paspalum. Além disto, os resultados indicaram que os híbridos $\mathrm{H} 12, \mathrm{H} 13$ e H2O são indicados para novas hibridações com o genitor sexual feminino, na obtenção de recombinantes elites.

Palavras-chave adicionais: apomixia; espécies forrageiras; melhoramento vegetal; variabilidade genética.

\section{Introduction}

In the Southern Cone region, native pasture covers countries such as Uruguay, Argentina and parts of Paraguay and Brazil. For many decades, this ecosystem has been crucial for natural resources conservation, such as water and soil, and in maintaining different highly adapted plant species (Nabinger et al., 2009, Brugnoli et al., 2013). Under these conditions, species from Paspalum genus, and particularly those of Plicatula group, showed high adaptability and wide intra and interspecific variability in forage interest characters (Pereira et al., 2012, Cidade et al., 2013). However, native forage species are being replaced by exotic cultivars that, even with high production potential, are often not adapted to local conditions, resulting in biological imbalance and yield losses (Nabinger et al., 2009, Pereira et al., 2012). 
Most Paspalum species have asexual reproduction by apomixis (Dall'agnol \& SchifinoWittmann, 2005). Apomixis reduces the occurrence of sexual reproduction limiting new genotypes formation, once that progeny are genetically identical to the mother plant (Brugnoli et al., 2013, Acunã et al., 2011). On the other hand, sexual plants with the same ploidy level allows allelic recombination using pollen from apomictic plants. This crossing type generates genetic variability, resulting in both sexual and apomictic progenies. Studies showed that sexuality is recessive in tetraploid Paspalum spp tetraploids, and apomixis is subjected to a single Mendelian inheritance dominant locus, although a distorted segregation was considered (Martínez et al., 2001, Dall'Agnol \& Schifino-Wittmann, 2005). In selection generation, those individuals that are identified as apomictic, which have higher agronomic potential, can be already selected in the first generation, since all characters will be determined due to the own apomixis event (Acuña et al., 2011). Sartor et al. (2009) artificially doubled P. plicatulum diploid sexual plants, obtaining sexual tetraploids that could be used in crosses with several other plant species belonging to the same taxonomic group, what was prevented before by apomixis. Aguilera et al. (2011) used the $P$. plicatulum "4c4x" genotype, which was artificially tetraploided as female parent in artificial hybridization with a native $P$. guenoarum genotype known as 'Rojas' (male parent), both belonging to the same Plicatula taxonomic group, and obtained 23 viable interspecific hybrids. Among Plicatula group species, guenoarum has higher forage and seeds production potential over the same group other species, and also within the whole Paspalum genus (Nabinger et al., 2009, Pereira et al., 2012).

Information on genetic variability, seeking promising combinations, can be estimated through predictive methods from agronomic, morphological and molecular characteristics (Cavers et al., 2005, Cidade et al., 2013). Therefore, several characters simultaneous evaluation can be an efficient tool to characterize populations, identify superior genotypes and assist in directing plant breeding future crosses (Sawasato et al., 2008). Thus, the knowledge on genetic variability on expression of characters among Paspalum genus genotypes, analyzed in field and DNA levels, may provide subsidies for superior plants selection and new hybridization targeting with sex parents, in search of elite recombinants.

The objective of this study was to analyze genetic variability, in the agronomic and molecular levels, of Paspalum genus apomictic genotypes, which were obtained by Paspalum plicatulum (sexual female parent) and Paspalum guenoarum (apomitic male parent) interspecific cross, aiming at foreseeing sexual parent promising combinations in characters related to forage production.

\section{Material and methods}

The experiment was carried in 2010 and 2011 in Eldorado do Sul and Augusto Pestana, State Rio Grande do Sul, Brazil. Eldorado do Sul experimental area is located in the "Depressão Central" region (300'을 experimental area is located in the northwestern region of Rio Grande do Sul state (28025'58"S and $\left.54^{\circ} 00^{\prime} 24 " \mathrm{~W}\right)$. Based on soil analysis, fertilization was performed with the 20-150-100 amount in Eldorado do Sul and with 20-120-100 in Augusto Pestana, with mixed NPK fertilizer. Afterwards, topdressing was applied at 180 and $130 \mathrm{~kg} \mathrm{ha}^{-1}$ nitrogen doses in Eldorado do Sul and Augusto Pestana, respectively. Applications were made in accordance with warm season perennial grasses technical indications, according to the Soil Analysis Laboratories Official Network (SBCS, 2004). The experimental unit was represented by a $1.8 \mathrm{~m}$ long line consisting of ten plants from each genotype, which were spaced apart by $30 \mathrm{~cm}$. Seedlings from all genotypes were used in order to ensure the experiment implementation. The experimental design was randomized blocks, with four repetitions at both sites. Seven hybrids, called $\mathrm{H} 3, \mathrm{H} 9$, $\mathrm{H} 12, \mathrm{H} 13, \mathrm{H} 16, \mathrm{H} 2 \mathrm{O}$ and $\mathrm{H} 22$ were used, in addition to their parents, identified as P. plicatulum "4c-4x" (sexual female parent) and $P$. guenoarum "Rojas" cultivar (male apomitic parent). Hybrids came from crosses performed in 2006 at the National University of the Northwest of Argentina, Corrientes province, Argentina, being identified as apomictic (Sartor et al., 2009; Aguilera et al., 2011). The study included two native genotypes ( $P$. guenoarum "Azulão" and "Baio") from UFRGS (Universidade Federal do Rio Grande do Sul) Forage Plants and Agrometeorology Department that stand out for high forage potential (Pereira et al., 2012). In addition, Pensacola cultivar ( $P$. notatum) was included, which comes from Southern Cone natural conditions and features high leaf/stem ratio and nutritional quality (Pereira et al., 2011). All individuals belong to Plicatula group, except for Pensacola, which is part of Notata group. The transplants occurred on $1^{\text {st }}$ and $4^{\text {th }}$ December, 2009, and assessment was carried out through cuts when plants reached $35 \mathrm{~cm}$ mean height, keeping a $10 \mathrm{~cm}$ soil residue for all genotypes, except for Pensacola cv., which was cut when reached $25 \mathrm{~cm}$ height, keeping $5 \mathrm{~cm}$ soil residue. Before cutting, tillers number per plant (TN) and vegetation cover diameter (VCD, in $\mathrm{cm}$ ) were determined. Subsequently, cuts were performed and samples were taken to the laboratory for leaves, stems, inflorescences and dead material morphological separation, being placed in a forced air oven at $65^{\circ} \mathrm{C}$ until constant weight. Analyzed characters were: total dry matter (TDM, g plant ${ }^{-1}$ ), leaves dry matter (LDM, $g$ plant $\left.{ }^{-1}\right)$, stem dry matter (SDM, g plant ${ }^{-1}$ ), inflorescence dry matter (IDM, g plant ${ }^{-1}$ ) and dead material dry matter (DMDM, g plant ${ }^{-1}$ ), and the leaf/stem ratio (LSR) was calculated by dividing LDM by SDM. Five cuts were 
carried out in the first year and six cuts in the second, in both places and in all genotypes, except for Pensacola cultivar, which allowed four and five cuts in the first and second year, respectively.

Data were subjected to analysis of variance for double factorial (genotypes $x$ sites) joint analysis, and their interactions were subjected to $F$ test at $5 \%$ probability. Analyzes showed data homogeneity, enabling the interpretation. Afterwards, mean cluster analysis by Scott \& Knott's test at 5\% probability was carried out. Furthermore, variables relative contribution to morphological variability within each site and also jointly was calculated using Singh's (1981) model. For this analyzes, Genes software (Cruz, 2007) was used. Based on character means, genetic distance matrices were constructed and dendrograms were produced by mean distance clustering method (MDCM) and Mahalanobis distance as genetic distance measure, and the adjustment between distance matrices and dendrograms was estimated by $r$ cophenetic correlation coefficient (Sokal \& Rohlf, 1962)

Molecular analysis with eleven microsatellite molecular markers (MMM) was performed. Young leaves were collected for DNA extraction using Ferreira \& Grattapaglia's (1998) protocol, with modifications. The action product was separated in $1.8 \%$ agarose gel using EDTA Tris-Borate (ETB). For gel bands visualization, $8 \mu \mathrm{l}$ ethidium bromide $(0.4 \mu \mathrm{l} / \mathrm{ml})$ was added. Gels were visualized under UV light and photographed with a EDAS 290 Kodak digital camera. Fragments were determined through comparison with the 100pb standard. From amplified fragments identification, data binary matrix was built, assigning 1 value for bands presence and zero for absence. From this matrix, and using the Jaccard's coefficient, a similarity matrix was generated for all genotypes comparison. Cluster analysis was performed from similarity coefficients between genotypes using the mean distance clustering method (MDCM) as grouping criteria. These analyzes were performed using the NTSYS pc 2.1 program (Rohlf, 2000).

\section{Results and discussions}

Based on joint analysis of variance, significance was observed to genotypes $(\mathrm{G})$ and sites (S) variation sources and $(G \times S)$ interaction on all forage characters. On Table 1, through Scott \& Knott's test, at Eldorado do Sul site, four distinct classes were formed to total dry matter. The male parent and $\mathrm{H} 12$ and $\mathrm{H} 20$ hybrids showed higher production. The female parent and Pensacola cultivar expressed the lowest values in this character. In Augusto Pestana, four classes were also formed, highlighting $\mathrm{H} 12$ and $\mathrm{H} 20$ hybrids, along with $\mathrm{H} 13$, H9 genotypes and Baio. In this condition, the " $b$ " class male parent proved to be similar to $\mathrm{H} 22, \mathrm{H} 3$, $\mathrm{H} 16$ and Azulão hybrids. As occurred in Eldorado do Sul, the female parent and Pensacola cultivar showed reduced performance. $\mathrm{H} 20, \mathrm{H} 13, \mathrm{H} 9, \mathrm{H} 3$ and $\mathrm{H} 16$ genotypes and their parents, Baio and Pensacola cultivar, had similar performances in relation to sites. To the other genotypes, Eldorado do Sul was more favorable to total dry matter expression. The total dry matter character is the most used in forage plants performance assessment and in variability detection among genotypes (Acunã et al., 2011, Pereira et al., 2012).

In Table 1, leaves dry matter indicated variability for both sites by the formation of four distinct groups. In Eldorado do Sul, H12, H20, H13, H22 and $\mathrm{H} 3$ hybrids and the male parent were the superior group. As occurred for total dry matter, the female parent and Pensacola cultivar indicated lower leaves production. In Augusto Pestana, H12, H2O and H13 hybrids showed superiority, including Baio genotype. In this environment, the female parent and Pensacola cultivar also indicated reduced performance (Table 1). Leaves dry matter and total dry matter are decisive characters in forage plants improvement, in order to obtain superior performance Paspalum cultivars (Pereira et al., 2012). It is noteworthy that the leaf is the organ preferentially consumed by animals and is the structure with the highest nutritional quality (Alexandrino et al., 2004, Bratti et al., 2009).

In the two most important characters analyzed in this study, all hybrids showed heterosis in both the TDM and LDM over parents mean (MP and FP). Heterosis pursuit in plant breeding is essential to breeding programs success, and obtaining these results with just one selection cycle increases elite cultivars release prospects and generates new recombinations within the Plicatula group. In Eldorado do Sul leaf/stem ratio, the female parent stood out compared to the others (Table 1). H12, H22, H9 and H3 hybrids, Azulão genotype and Pensacola had intermediate performance. In Augusto Pestana, $\mathrm{H} 20$ and Pensacola expressed higher leaf/stem ratio. The female parent, $\mathrm{H} 13$ and Baio had intermediate performance. $\mathrm{H} 20$ and $\mathrm{H} 13$ hybrids, the male parent and Azulão had lower performance, regardless of site. The higher leaf/stem ratio is related to a more nutritious structure development capacity, as leaves have higher digestibility and crude protein, with lower fiber content compared to the stem (Gontijo Neto et al., 2006, Pereira et al., 2011). In tillers number per plant analysis, H2O hybrid surpassed all others, including their parents (Table 1). In Augusto Pestana, $\mathrm{H} 20, \mathrm{H} 13$ and $\mathrm{H} 12$ hybrids were the most significant. There, Pensacola cultivar had the lowest character performance. Tillering directly related to persistence capacity (Sbrissia \& Da Silva, 2008), seed yield and forage production, which are important in species analysis with forage capacity (Lopes \& Franke, 2011). Pereira et al. (2012), while studying Paspalum apomictic genotypes, have not observed differences in tillering, suggesting crossings with sexual plants with more tillers, in order to generate variability. 
Table 1 - Forage characters mean values for Paspalum spp. genus genotypes conducted in Eldorado do Sul (ES) and Augusto Pestana (AP)-RS, Brazil.

\begin{tabular}{|c|c|c|c|c|c|c|c|c|}
\hline \multirow{2}{*}{ Genotypes } & \multicolumn{2}{|c|}{ TDM } & \multicolumn{2}{|c|}{ LDM } & \multicolumn{2}{|c|}{ LSR } & \multicolumn{2}{|c|}{ TN } \\
\hline & ES & AP & ES & $\mathrm{AP}$ & ES & $\mathrm{AP}$ & ES & $\mathrm{AP}$ \\
\hline & \multicolumn{8}{|c|}{ Joint Analysis $(2010+2011)$} \\
\hline $\mathrm{H} 12$ & $377 \mathrm{Aa}$ & $278 \mathrm{Ba}$ & $276 \mathrm{Aa}$ & $206 \mathrm{Ba}$ & $3.2 \mathrm{Ab}$ & $3.1 \mathrm{Ab}$ & $100 \mathrm{Aa}$ & $99 \mathrm{Aa}$ \\
\hline $\mathrm{H} 2 \mathrm{O}$ & $358 \mathrm{Aa}$ & $291 \mathrm{Aa}$ & $239 \mathrm{Aa}$ & $223 \mathrm{Aa}$ & $2.4 \mathrm{Bc}$ & 3.7 Aa & $72 \mathrm{Bb}$ & $99 \mathrm{Aa}$ \\
\hline $\mathrm{H} 13$ & $296 \mathrm{Ab}$ & $289 \mathrm{Aa}$ & $213 \mathrm{Aa}$ & $216 \mathrm{Aa}$ & $2.7 \mathrm{Ac}$ & $3.1 \mathrm{Ab}$ & $77 \mathrm{Bb}$ & $100 \mathrm{Aa}$ \\
\hline $\mathrm{H} 22$ & $305 \mathrm{Ab}$ & $225 \mathrm{Bb}$ & $228 \mathrm{Aa}$ & $153 \mathrm{Bb}$ & $3.2 \mathrm{Ab}$ & $2.1 \mathrm{Bc}$ & $80 \mathrm{Ab}$ & $77 \mathrm{Ab}$ \\
\hline H9 & $224 \mathrm{Ab}$ & $281 \mathrm{Aa}$ & $162 \mathrm{Ab}$ & $179 \mathrm{Ab}$ & $3.0 \mathrm{Ab}$ & $1.9 \mathrm{Bc}$ & $83 \mathrm{Ab}$ & $85 \mathrm{Ab}$ \\
\hline $\mathrm{H} 3$ & $272 A b$ & $221 \mathrm{Ab}$ & $206 \mathrm{Aa}$ & $145 \mathrm{Bb}$ & $3.5 \mathrm{Ab}$ & $2.0 \mathrm{Bc}$ & $82 A b$ & $79 \mathrm{Ab}$ \\
\hline $\mathrm{H} 16$ & $249 A b$ & $221 \mathrm{Ab}$ & $164 \mathrm{Ab}$ & $157 \mathrm{Ab}$ & $2.0 \mathrm{Bc}$ & $2.7 \mathrm{Ac}$ & $60 \mathrm{Ac}$ & $68 \mathrm{Ac}$ \\
\hline MP & $328 \mathrm{Aa}$ & $249 \mathrm{Bb}$ & $215 \mathrm{Aa}$ & $168 \mathrm{Ab}$ & $2.1 \mathrm{Ac}$ & $2.4 \mathrm{Ac}$ & $60 \mathrm{Ac}$ & $74 \mathrm{Ac}$ \\
\hline FP & $119 \mathrm{Ac}$ & $162 \mathrm{Ac}$ & $98 \mathrm{Ac}$ & $108 \mathrm{Ac}$ & $5.4 \mathrm{Aa}$ & $3.1 \mathrm{Bb}$ & $74 \mathrm{Ab}$ & $67 \mathrm{Ac}$ \\
\hline Baio & $267 \mathrm{Ab}$ & $283 \mathrm{Aa}$ & $171 \mathrm{Ab}$ & $196 \mathrm{Aa}$ & $2.1 \mathrm{Bc}$ & $2.9 \mathrm{Ab}$ & $55 \mathrm{Ac}$ & $66 \mathrm{Ac}$ \\
\hline Azulão & $300 \mathrm{Ab}$ & $225 \mathrm{Bb}$ & $198 \mathrm{Ab}$ & $155 \mathrm{Ab}$ & $2.9 \mathrm{Ab}$ & $2.2 \mathrm{Ac}$ & $56 \mathrm{Bc}$ & $81 \mathrm{Ab}$ \\
\hline Pensacola & $30 \mathrm{Ad}$ & $38 \mathrm{Ad}$ & $18 \mathrm{Ad}$ & $25 \mathrm{Ad}$ & $3.3 \mathrm{Bb}$ & $3.9 \mathrm{Aa}$ & $42 \mathrm{Ac}$ & $37 \mathrm{Ad}$ \\
\hline \multirow{2}{*}{ Genotypes } & \multicolumn{2}{|c|}{ VCD } & \multicolumn{2}{|c|}{ SDM } & \multicolumn{2}{|c|}{ IDM } & \multicolumn{2}{|c|}{ DMDM } \\
\hline & ES & $\mathrm{AP}$ & ES & $\mathrm{AP}$ & ES & $\mathrm{AP}$ & ES & $\mathrm{AP}$ \\
\hline & \multicolumn{8}{|c|}{ Joint Analysis $(2010+2011)$} \\
\hline $\mathrm{H} 12$ & $46 \mathrm{Aa}$ & $33 \mathrm{Ba}$ & $88 \mathrm{Ab}$ & $66 \mathrm{Ba}$ & $14 \mathrm{Aa}$ & $5 \mathrm{Bb}$ & $9 \mathrm{Ba}$ & $23 \mathrm{Aa}$ \\
\hline $\mathrm{H} 2 \mathrm{O}$ & $44 \mathrm{Aa}$ & $36 \mathrm{Ba}$ & $114 \mathrm{Aa}$ & $66 \mathrm{Ba}$ & $5 \mathrm{Ab}$ & $2 A b$ & $9 \mathrm{Aa}$ & $11 \mathrm{Ac}$ \\
\hline $\mathrm{H} 13$ & $39 \mathrm{Ab}$ & $32 \mathrm{Ba}$ & $80 \mathrm{Ac}$ & $68 \mathrm{Aa}$ & $4 \mathrm{Ab}$ & $6 \mathrm{Ab}$ & $9 \mathrm{Ba}$ & $15 \mathrm{Ab}$ \\
\hline $\mathrm{H} 22$ & $40 \mathrm{Ab}$ & $28 \mathrm{Bb}$ & $74 \mathrm{Ac}$ & $66 \mathrm{Aa}$ & $3 \mathrm{Ab}$ & $6 \mathrm{Ab}$ & $4 \mathrm{Bb}$ & $9 \mathrm{Ac}$ \\
\hline $\mathrm{H} 9$ & $38 \mathrm{Ab}$ & $33 \mathrm{Ba}$ & $57 \mathrm{Ac}$ & $87 \mathrm{Aa}$ & $3 \mathrm{Bb}$ & $15 \mathrm{Aa}$ & $7 \mathrm{Ba}$ & $19 \mathrm{Ab}$ \\
\hline $\mathrm{H} 3$ & $38 \mathrm{Ab}$ & $29 \mathrm{Bb}$ & $63 \mathrm{Ac}$ & $64 \mathrm{Aa}$ & $2 \mathrm{Bb}$ & $12 \mathrm{Aa}$ & $9 \mathrm{Aa}$ & $12 \mathrm{Ac}$ \\
\hline $\mathrm{H} 16$ & $37 \mathrm{Ab}$ & $28 \mathrm{Bb}$ & $72 \mathrm{Ac}$ & $56 \mathrm{Aa}$ & $13 \mathrm{Aa}$ & $7 \mathrm{Bb}$ & $8 \mathrm{Aa}$ & $5 \mathrm{Ad}$ \\
\hline MP & $45 \mathrm{Aa}$ & $34 \mathrm{Ba}$ & $105 \mathrm{Aa}$ & $70 \mathrm{Ba}$ & $8 \mathrm{Ab}$ & $11 \mathrm{Aa}$ & $5 \mathrm{Bb}$ & $20 \mathrm{Aa}$ \\
\hline FP & $27 \mathrm{Ac}$ & $24 \mathrm{Ac}$ & $17 \mathrm{Bd}$ & $35 \mathrm{Aa}$ & $4 \mathrm{Ab}$ & $4 \mathrm{Ab}$ & $2 \mathrm{Bb}$ & $6 \mathrm{Ad}$ \\
\hline Baio & $39 \mathrm{Ab}$ & $30 \mathrm{Bb}$ & $90 \mathrm{Ab}$ & $77 \mathrm{Aa}$ & $6 \mathrm{Ab}$ & $10 \mathrm{Aa}$ & $67 \mathrm{Ba}$ & $18 \mathrm{Ab}$ \\
\hline Azulão & $36 \mathrm{Ab}$ & $30 \mathrm{Bb}$ & $95 \mathrm{Ab}$ & $60 \mathrm{Ba}$ & $7 \mathrm{Ab}$ & $9 \mathrm{Ba}$ & $10 \mathrm{Ba}$ & $23 \mathrm{Aa}$ \\
\hline Pensacola & $24 \mathrm{Ac}$ & $18 \mathrm{Bd}$ & $8 \mathrm{Ad}$ & $10 \mathrm{Aa}$ & $4 \mathrm{Ab}$ & $3 \mathrm{Ab}$ & $1 \mathrm{Ab}$ & $1 \mathrm{Ae}$ \\
\hline
\end{tabular}

${ }^{\star}$ Means followed by the same letters, uppercase in lines and lowercase in columns or in the same character do not differ by Scott \& Knott's test at $5 \%$ probability. TDM - total dry matter (g plant $\left.{ }^{-1}\right)$; LDM - leaves dry matter (g plant ${ }^{-1}$ ); LSR - leaf/stem ratio (LDM / SDM); TN - tillers number ( $g$ plant $\left.^{-1}\right)$; VCD - vegetation cover diameter; SDM - Stem dry matter (g plant $\left.{ }^{-1}\right)$; IDM - inflorescence dry matter (g plant $\left.{ }^{-1}\right)$; DMDM - dead material dry matter (g plant $\left.{ }^{-1}\right)$; MP - male parent; FP - female parent.

On vegetation cover diameter character, the male parent and $\mathrm{H} 12$ and $\mathrm{H} 20$ hybrids had the highest means in Eldorado do Sul (Table 1). Comparing the sites, sexual plant showed no change, although others had higher expression in Eldorado do Sul. On stem dry matter, the H2O hybrid and the male parent were more expressive. On the other hand, there was no variation among genotypes in Augusto Pestana (Table 1). On inflorescence dry matter there was little variability. $\mathrm{H} 12$ and $\mathrm{H} 16$ hybrids were higher in floral induction compared to the others. In Augusto Pestana, H9 and $\mathrm{H} 3$ hybrids, along with the male parent, Azulão and Baio, showed higher inflorescences production (Table 1). In the dead material dry matter, there was little change in Eldorado do Sul, with only two classes (Table 1). On the other hand, five classes were obtained in Augusto Pestana, highlighting higher expression in $\mathrm{H} 12$ genotypes $\mathrm{H} 12$, male parent and Azulão. Vegetation cover diameter is connected to soil shading capacity, persistence and competitive ability against invaders (Acunã et al., 2011). Inflorescence dry matter character is connected directly to seed production and should be separately analyzed from studies aimed at forage production (Lopez et al., 2011). Dead material accumulation indicates higher plant morphological structures refresh rate, suggesting consumption by animals or cutting to be carried out more frequently. According to SANTOS et al. (2004), plants with low leaf availability and high stem and dead material production are generally little consumed, resulting in lower animal production.

In order to estimate Paspalum agronomic 
characters genetic variability, the dendrogram by Mahalanobis distance in the cultivation years mean analysis is shown in Figure 1. In Eldorado do Sul, four groups formation (Figure 1a) was observed. The first was formed by $\mathrm{H} 12, \mathrm{H} 13, \mathrm{H} 9$ and $\mathrm{H} 3$ hybrids. The second was formed by $\mathrm{H} 2 \mathrm{O}, \mathrm{H} 22$ and $\mathrm{H} 16$ hybrids, Baio, Azulão and the male parent. The third was only represented by Pensacola cultivar and Group 4 by the sexual female parent. It is noteworthy that the male parent brings higher similarity to formed progenies, unlike the isolation obtained from the female parent. Therefore, most of hybrids reveal sexual female parent genetic distance, showing the possibility of new crossings, aimed at elite recombinants. In Augusto Pestana, four groups were also obtained (Figure 1b).
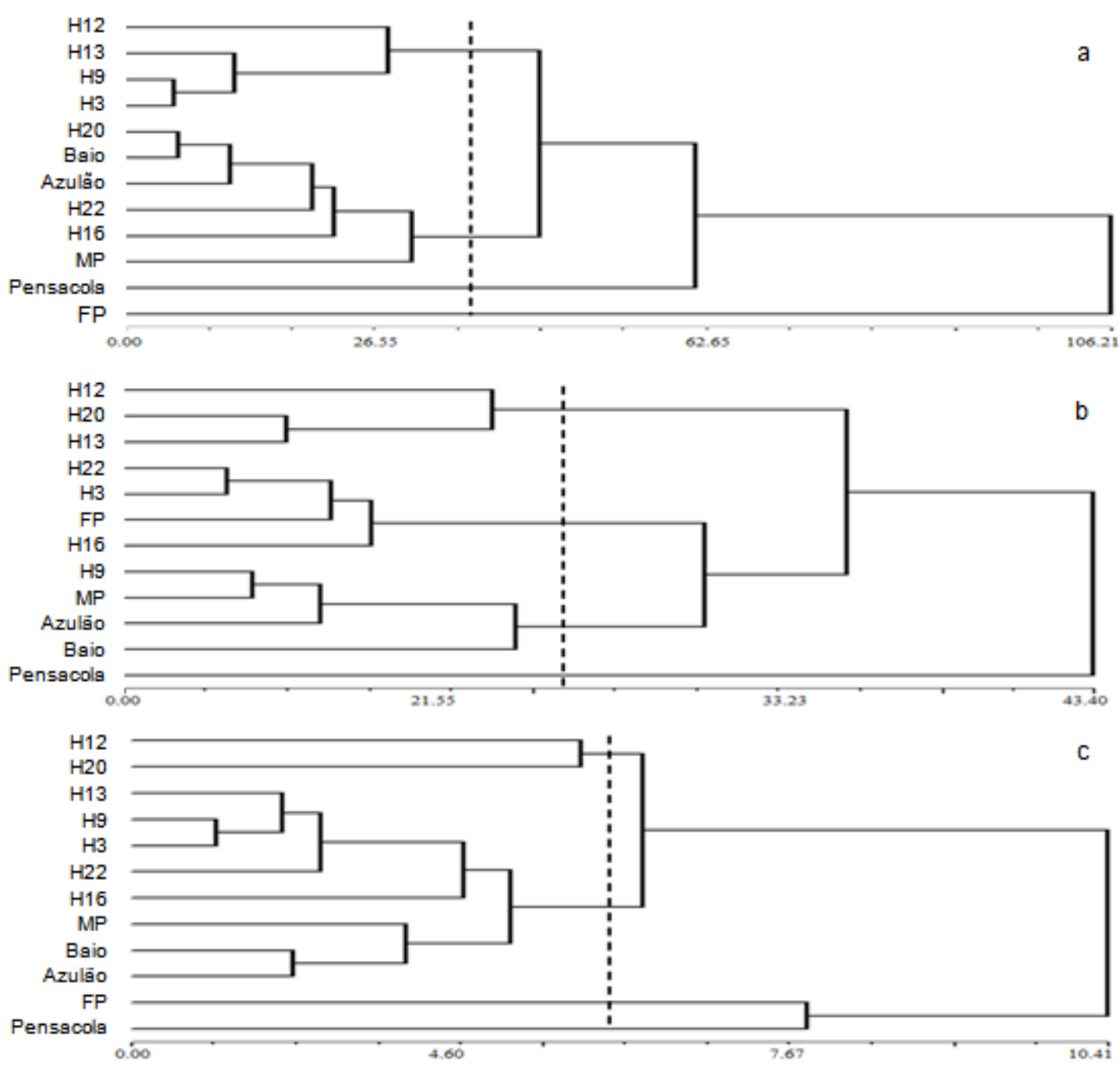

Figure 1 - Analysis dendrogram of 12 Paspalum spp.genotypes obtained by MDCM grouping method, using the Mahalanobis model as genetic distance measure. MP - Male parent; FP - Female parent. a) Eldorado do Sul. b) Augusto Pestana. c) Conjunct analysis.

Group I was formed by $\mathrm{H} 12, \mathrm{H} 20$ and $\mathrm{H} 13$ hybrids. Group II was formed by H22, H3, H16 genotypes similarity, including the sexual female parent. Group III was formed by H9, apomitic male parent, Azulão and Baio, and Group IV was formed by Pensacola cultivar alone. Results show promising recombination possibility of group I $\mathrm{H} 12$ hybrid and group II H2O with the sexual female parent, because, besides evidencing high total dry matter, leaves dry matter and vegetation cover diameter mean values
(Table 1), regardless of site, they composed a distinct group from their sex parent. However, in the dendrogram involving the cultivation sites joint analysis (Figure 1c), results reinforce previously reported observations, showing $\mathrm{H} 20$ and $\mathrm{H} 12$ genotypes being similar to each other and genetically distant from their parents, including the same crossing other hybrids. Therefore, genetically distant parents with high interest character means are decisive for increased variability and superior performance transgressive recombinants 
obtainment (Benin et al., 2003).

In variables relative contribution analysis on total variability (Table 2), Eldorado do Sul total dry matter and leaf/stem ratio showed the highest contribution. In Augusto Pestana, leaves dry matter was the most effective, including important contributions by total dry matter, leaf/stem ratio and vegetation cover diameter. In the general condition, through years and site joint analysis, total dry matter, leaves dry matter and leaf/stem ratio proved decisive in providing the best agronomic variability design in Paspalum genus species. Similar results were also obtained by Pereira et al. (2012), while assessing Paspalum apomictic access. It is noteworthy that characters that little contribute to genetic variability should be avoided due to the time spent and the low breeding efficiency (Alves et al., 2003; Pereira et al., 2012).

Table 2 - Variables relative contribution to the general variability observed in Paspalum spp forage characters.

\begin{tabular}{|c|c|c|c|c|c|c|}
\hline \multirow{2}{*}{ Characters } & \multicolumn{2}{|c|}{ Eldorado do Sul } & \multicolumn{2}{|c|}{ Augusto Pestana } & \multicolumn{2}{|c|}{ General } \\
\hline & Sj & Sj (\%) & Sj & Sj (\%) & Sj & Sj (\%) \\
\hline TDM & 1463 & 35.8 & 56 & 14.4 & 1380 & 46.2 \\
\hline LDM & 290 & 7.1 & 82 & 36.3 & 805 & 27.0 \\
\hline LSR & 1058 & 25.9 & 217 & 16.9 & 38 & 10.3 \\
\hline $\mathrm{TN}$ & 319 & 7.8 & 41 & 3.2 & 69 & 2.3 \\
\hline VCD & 316 & 7.7 & 452 & 15.1 & 198 & 6.6 \\
\hline SDM & 538 & 13.1 & 16 & 1.3 & 391 & 6.1 \\
\hline IDM & 106 & 2.6 & 64 & 5.0 & 12 & 0.4 \\
\hline DMDM & 3 & 0.1 & 359 & 7.8 & 92 & 3.1 \\
\hline
\end{tabular}

Sj - Relative contribution; Sj (\%) - relative contribution percentage; TDM - total dry matter ( p plant $^{-1}$ ); LDM - leaves dry matter (g plant $\left.{ }^{-1}\right)$; LSR - leaf/stem ratio (LDM / SDM); TN - tillers number ( $g$ plant ${ }^{-1}$ ); VCD - vegetation cover diameter; SDM - Stem dry matter (g plant $\left.{ }^{-1}\right)$ I IDM - inflorescence dry matter (g plant $\left.{ }^{-1}\right)$; DMDM - dead material dry matter (g plant $\left.{ }^{-1}\right)$.

In Paspalum spp. DNA level genetic variability study (Figure 2), ten MMM markers allowed amplification. The highest mean distance was obtained between the sexual female parent and the H9 hybrid, and the lowest was obtained between Baio and Pensacola cultivar. The unique grouping between sexual and apomictic parents was unusual, showing genetic distance with this crossing other progenies. This is a condition that strengthens genetic variability studies importance among apomictic progenies, and new combinations use at the crossing with the same sex parent. In the dendrogram, the largest group was composed by Azulão, H20, Baio, Pensacola, H12, H3, $\mathrm{H} 16$ and $\mathrm{H} 9$ genotypes. $\mathrm{H} 13$ and $\mathrm{H} 22$ genotypes composed isolated groups. Although $P$. notatum species Pensacola cultivar belongs to the Notata taxonomic group (Cidade et al., 2013), it showed high similarity bond with Baio, what denotes the higher gene transfer possibility between the two species.

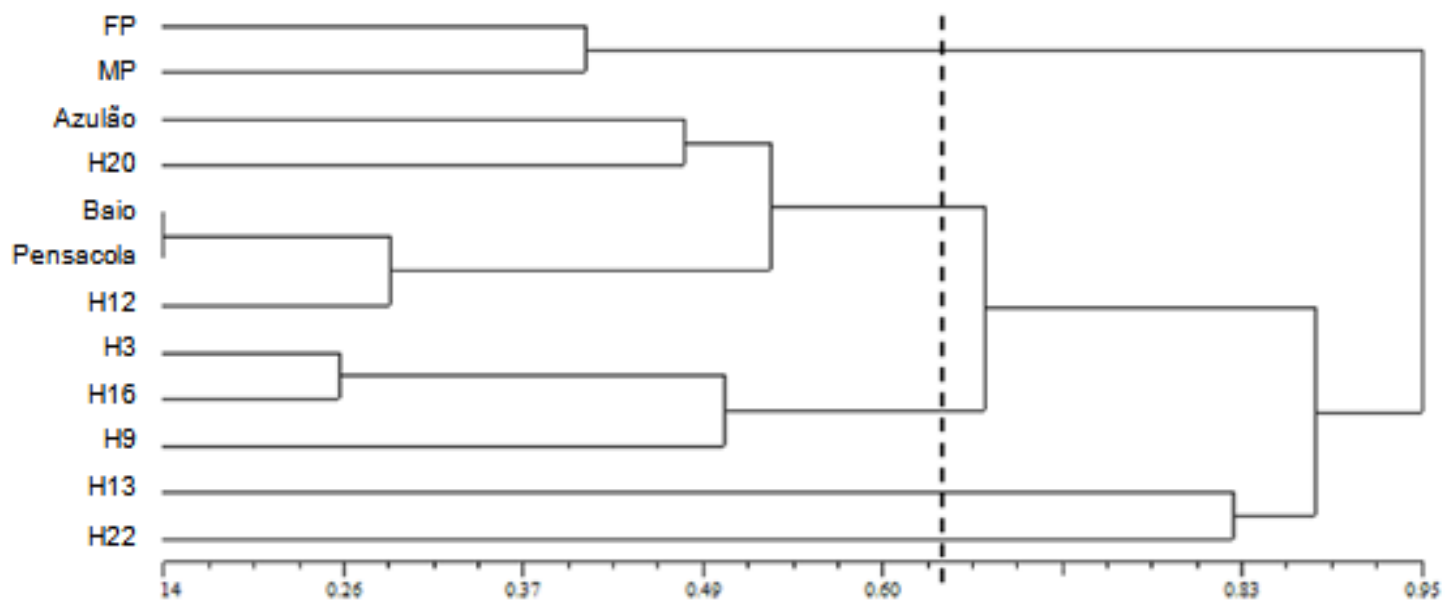

Figure 2 - 12 Paspalum spp. genotypes dendrogram constructed from amplification products with MMM primers, using the MDCM grouping method. MP - Male parent; FP - Female parent. 
It is noteworthy that differences obtained in the grouping between molecular and phenotypic technique were expected, because a reduced correlation has been detected between the two assessment forms in the literature. Furthermore, a technique that allows access to a large number of DNA segments at molecular level comparison would not have differentiation capacity in relation to phenotypic characteristics analyzed number. Regarding the weak association found between estimated distances on molecular and phenotypic data, this low correlation could be due to an incomplete genome representation when morphological data are used (Vieira et al., 2005, Cidade et al., 2013). Although morphological analysis allows access to fewer characters, it represents effective variations in relation to the study interest agronomic characteristics, and is often more effective in comparison to plant breeding programs. Genetic variability assessment using microsatellite markers is considered an excellent tool in breeding programs, and is used in several other species, such as Paspalum urvillei, $P$. vaginatum, Zea mays, Oryza Sativa, Sorghum bicolor, among others (Wang et al., 2006, Sawasato et al., 2008). Molecular techniques combined with agronomic and morphological information contributes to breeding programs efficiency (Pereira et al., 2012, Cidade et al., 2013).

Agronomic and molecular level dendrograms prove to be important in helping new crossings orientation through different groups apomictic hybrids use to sexual compatible plants hybridizations. On the other hand, high forage production and genotypes good adaptability to the most varied environments should be observed. These conditions are essential to obtain more productive genotypes, joying benefits from interspecific heterosis and easier selection by quick genotype obtainment via apomixis.

\section{Conclusions}

Agronomic and molecular level analysis were able to detect genetic variability different forms between Paspalum interspecific hybrids.

$\mathrm{H} 12, \mathrm{H} 13$ and $\mathrm{H} 20$ hybrids are suitable for female sexual parent new hybridization, in order to obtain elite recombinants, as well as being suitable to a commercial cultivar release breeding program subsequent steps.

\section{Aknowledgement}

Thanks to CNPq, CAPES, UNIJUÍ and Sulpasto by financial support and human resources. Thanks to the Del Nordeste-Argentina Botany Institute, in the person of Dr. Camilo Quarin, for providing the hybrids.

\section{References}

Acunã CA, Blount AR, Quesenberry KH, Kenworthy KE, Hanna WW (2011) Tetraploid bahiagrass hybrids: breeding technique, genetic variability and proportion of heterotic hybrids. Euphytica 179(2):227-235.
Aguilera PM, Sartor ME, Galdeano F, Espinoza F, Quarin CL (2011) Interspecific tetraploid hybrids between two forage grass species: sexual Paspalum plicatulum and apomictic $P$. guenoarum. Crop Science 51(4):1544-1550.

Alexandrino E, Nascimento Júnior D, Mosquim PR, Regazzi AJ, Rocha FC (2004) Características morfogênicas e estruturais na rebrotação da Brachiaria brizantha cv. marandu submetida a três doses de nitrogênio. Revista Brasileira de Zootecnia 33(6):1372-1379.

Alves RM, Garcia AAF, Cruz ED, Figueira A (2003) Seleção de descritores botânico-agronômicos para caracterização de germoplasma de cupuaçuzeiro. Pesquisa Agropecuária Brasileira 38(7): 807-818.

Benin G, Carvalho FIF De, Oliveira AC De, Marchioro VS, Lorencetti C, Kurek AJ, Silva JAG Da, Cruz PJ, Hartwig I, Schimidt D AM (2003) Comparações entre medidas de dissimilaridade e estatísticas multivariadas como critérios no direcionamento de hibridações em aveia. Ciência Rural 33(4):657-662

Bratti LFS, Dittrich JR, Barros CS De, Silva CJA Da, Monteiro ALG, Rocha C Da, Rocha FMP da (2009) Comportamento ingestivo de caprinos em pastagem de azevém e aveia-preta em cultivo puro e consorciado. Ciência Animal Brasileira 10(2):397-405.

Brugnoli EA, Urbani MH, Quarin CL, Martínez EJ, Acunã CA (2013) Diversity in diploid, tetraploid, and mixed diploid-tetraploid populations of Paspalum simplex. Crop Science 53(4):1509-1516.

Cavers S, Degen B, Caron H, Lemes MR, Margis R, Salgueiro F, Lowe AJ. (2005) Optimal sampling strategy for estimation of spatial genetic structure in tree populations. Heredity 95(4):281-289.

Cidade FW, Vigna BBZ, Souza FHD De, Valls JFM, Dall'agnol M, Zucchi MI, Souza-Chies TT De, Souza AP (2013) Genetic variation in polyploid forage grass: Assessing the molecular genetic variability in the Paspalum genus. BioMed Central Genetics 14(1):1-18.

Cruz CD (2007) Programa GENES: aplicativo computacional em genética e estatística. Viçosa: UFV.

Dall'agnol M, Schifino-Wittmann MT (2005) Apomixia, Genética e Melhoramento de Plantas. Revista Brasileira de Agrociência 11(2):127-133.

Ferreira ME, Grattapaglia D (1998) Introdução ao uso de marcadores moleculares em análise genética. $3^{\text {a }}$ ed. Brasília: EMBRAPA-CENARGEN. 220p.

Gontijo Neto MM, Euclides VPB, Nascimento Júnior D, Miranda LF, Fonseca D M Da, Oliveira MD De (2006) Consumo e tempo diário de pastejo por novilhos Nelore em pastagem de capim tanzânia sob diferentes ofertas de forragem. Revista Brasileira de Zootecnia 35(1):60-66 
Lopes RR, Franke LB (2011) Correlação e análise do coeficiente de trilha dos componentes do rendimento de sementes de grama-forquilha. Revista Brasileira de Zootecnia 40(5):972-977.

Martínez EJ, Urbani MH, Quarín CL, Ortiz JPA (2001) Inheritance of apospory in bahiagrass, Paspalum notatum. Hereditas 135:19-25.

Nabinger C, Ferreira ET, Freitas AK, Carvalho PCF, Sant'anna DM (2009) Produção animal com base no campo nativo: aplicações de resultados de pesquisa. In.: Pillar VD, Müller SC, Castilhos ZMS, Jacques AVA (Eds). Campos Sulinos: Conservação e Uso Sustentável da Biodiversidade. Brasília: Ministério do Meio Ambiente. p.175-198.

Pereira EA, Dall'agnol M Nabinger C, Huber KGC, Montardo DP, Genro TCM (2011) Produção agronômica de uma coleção de acessos de Paspalum lepton Parodi. Revista Brasileira de Zootecnia 40(3):498-508.

Pereira EA, Barros T, Volkmann GK, Battisti GK, Silva JAG Da, Simioni C, Dall'agnol M (2012) Variabilidade genética de caracteres forrageiros em Paspalum. Pesquisa Agropecuária Brasileira 47(10):1678-1540.

Rohlf FJ (2000) NTSYS-pc: numerical taxonomy and multivariate analysis system, version 2.1. New York: Exeter Software: 83p.

Santos EDG, Paulino MF, Queiroz DS, Fonseca DM Da, Valadares Filho SC, Lana RP (2004) Avaliação de pastagem diferida de Brachiaria decumbens Stapf. 2. Disponibilidade de forragem e desempenho animal durante a seca. Revista Brasileira de Zootecnia 33(1):214-224.

Sartor ME, Quarin CL, Espinoza F (2009) Mode of reproduction of colchicine-induced Paspalum plicatulum tetraploids. Crop Science 49(4):1270-1276.
Sawasato JT, Dall'agnol M, Conceição DP Da, Tafernaberri Júnior V, Klafke GB (2008) Utilização de microssatélites e RAPD na caracterização molecular de acessos de Paspalum urvillei Steudel. Revista Brasileira de Zootecnia 37(8):1366-1374.

Sbrissia AF, Da Silva SC (2008) Compensação tamanho/densidade populacional de perfilhos em pastos de capim-marandu. Revista Brasileira de Zootecnia 37(1):35-47.

Singh, D (1981) The relative importance of characters affecting genetic divergence. The Indian Journal of Genetic and Plant Breeding 41(2):237-245.

SBCS - SOCIEDADE BRASILEIRA DE CIÊNCIA DO SOLO (2004) Comissão de Fertilidade do Solo RS/SC. Manual de adubação e calagem para os Estados do Rio Grande do Sul e de Santa Catarina. 10. ed. Porto Alegre. 400p.

Sokal RR, Rohlf FJ (1962) The comparison of dendrograms by objective methods. Taxon 11(2):3340.

Vieira EA, Carvalho FIF, Oliveira AC, Benin G, Zimmer PD, Silva JAG, Martins AF, Bertan I, Silva GO, Schmidt DAM (2005) Comparação entre medidas de distância genealógica, morfológica e molecular em aveia em experimentos com e sem a aplicação de fungicida. Bragantia 64(1):51-60.

Wang ML, Chen ZB, Barkley NA, Newman ML, Kim W,Raymer P, Pederson GA (2006) Characterization of seashore paspalum (Paspalum vaginatum Swartz) germplasm by transferred SSRs from wheat, maize and sorghum. Genetic Resources and Crop Evolution 53(4):779-791. 